\section{Diallel analysis in cotton (Gossypium hirsutum L.) for water stress tolerance}

\section{Ubieli Alves Araújo Vasconcelos ${ }^{1^{*}}$, José Jaime Vasconcelos Ca- valcanti ${ }^{2}$, Francisco José Correia Farias ${ }^{2}$, Walmir Sousa Vascon- celos $^{3}$ and Roseane Cavalcanti dos Santos ${ }^{2}$}

\begin{abstract}
Information about combining ability is important in determining breeding strategies. The objective of this study was to estimate the general (GCA) and specific (SCA) combining abilities among twenty cotton hybrid combinations submitted to water stress, based on agronomic traits. The trails were carried out in semiarid environment (Barbalha, CE), during two years, in dry season under irrigation, and submitted to 23 days of water suppression. Wide variability was verified among parents and their hybrids, with additive effects to seed yield, lint percentage, blooming and boll weight. Dominance effect was found only to plant height. The combinations BRS $286 \times$ CNPA 5M, BRS RUBI x CNPA 5M, FM $966 \times$ CNPA 5M and BRS $286 \times$ BRS Seridó showed the best SCAs and averages for the majority of the traits. In addition, at least one of their parents had high CGA. These combinations must be advanced in cotton breeding program.
\end{abstract}

Key words: Breeding, combining ability, drought tolerance, genetic control, hybrid.

\section{INTRODUCTION}

Cotton (Gossypium hirsutum L.) is one of the most important textile crop worldwide. It is cultivated on about 35 million hectares, generating a global production of 24 million tons of fiber (Abrapa 2016). China, India, United States, Pakistan and Brazil are the main fiber producers (FAO 2016). The crop management involves more than 350 million people, in Brazilian cotton belt, located at Cerrado region, with production exceeded 1.5 million tons (Abrapa 2016, Conab 2016).

Cotton plant has a phenological cycle ranging from 120 to 200 days, depending on the cultivar, with different responses to environment conditions in order to ensure the fiber yield. Reproductive phase are quite dependent on water and fertilization supplements. According to Batista et al. (2010), water suppression in cotton plants for 23 days causes reduction in plant height, fiber growth, bud and boll numbers, although root system length is increased as a response to dry condition.

In Brazil, the main commercial cultivars have limited adaptation to environments with water irregularities. Considering the current climate changes faced on last decades, especially those related to water scarcity, the identification of cultivars with ability to adapt to environments with water restriction is a valuable strategy adopted in several crop breeding programs. Therefore, the generation
Crop Breeding and Applied Biotechnology 18: 24-30, 2018 Brazilian Society of Plant Breeding. Printed in Brazil http://dx.doi.org/10.1590/1984$70332018 v 18 n 1 a 4$
${ }^{*}$ Corresponding author:
E-mail: ubieli_araujo@hotmail.com

Received: 14 October 2016 Accepted: 01 July 2017

${ }^{1}$ Universidade Federal de Viçosa, Departamento de Fitotecnia, Campus Universitário S/N, 36.570-900, Viçosa, MG, Brazil ${ }^{2}$ Embrapa Algodão, 58.428-095, Campina Grande, PB, Brazil ${ }^{3}$ Universidade Estadual da Paraíba, Departamento de Ciências Agrárias e Exatas, 58.429500, Campina Grande, PB, Brazil 
of populations with broad genetic base is necessary in order to increase the chances to identify water-tolerant materials in further selection procedures. Diallelic design is often adopted to study genetic inheritance of traits, supporting in breeding strategy, as selection of individuals to create a breeding population. The scheme consists in crossings among the parents, resulting in hybrids with all possible combinations and providing combining ability of the parents.

The estimative of general combining ability (GCA) refers to capability of parental to generate favorable combinations in order to promote genes predominantly additive. The higher values estimated, positive or negative, the parent is considered higher or lower than others included in a diallel. By other side, the specific combining ability (SCA) refers to dominance effects and also to non-additive interactions of genes, resulting from gene complementation between parents. Then, the hybrid combination that shows high SCA $\left(\hat{s}_{i j}\right)$ and at least one parent with high GCA will be the most favorable (Cruz et al. 2012).

Several studies have been available in literature reporting on diallel analysis in cotton. Raza et al. (2013) evaluated five cultivars and detected additive effects to plant height, lint yield, lint percentage and boll weight. Khan and Hassan (2011) estimated the GCA and SCA in a diallel scheme involving 12 cotton cultivars and found differences in all hybrid combinations to lint yield, boll weight and boll numbers, with more genetic variances to SCA than to GCA indicating predominance of non-additive gene.

The genetic study of cotton under water restriction can support the cotton breeding program in semiarid environments. Thus, the objective of this research was to evaluate the hybrid combination, with the diallel design under water stress condition in order to identify the best combinations to water stress tolerance, based on GCA and SCA estimates.

\section{MATERIAL AND METHODS}

Twenty $F_{1}$ hybrid combinations generated from partial diallel crossing were used for this study using two parents groups: GI - formed by five cultivars with high fiber yield (Cia et al. 2014, Carvalho et al. 2015, Coutinho et al. 2015, Zonta et al. 2016) and GII - composed of by four drought tolerance cultivars (Freire et al. 1999, Vidal Neto and Freire 2013). These cultivars are inbred lines developed by Brazilian Company of Agricultural Research (Embrapa), Bayer and Mato Grosso Foundation (FMT) (Table 1).

The trials were carried out in Embrapa Cotton Experimental Station, in Barbalha (lat $7^{\circ} 18^{\prime} 18^{\prime \prime} \mathrm{S}$, long $39^{\circ} 18^{\prime} 7^{\prime \prime} \mathrm{W}$, alt $414 \mathrm{~m}$ asl), CE, in two years, during the dry season (July to December, 2014 and 2015). The mean of temperature recorded during the trial was $24.1^{\circ} \mathrm{C}$. The soil is classified as Fluvic Neosoil, clay loam texture (Embrapa 1999). Based on fertilization soil analysis, a previous fertilization was performed by using $250 \mathrm{~kg} \mathrm{ha}^{-1}$ of monoammonium phosphate (MAP) at sowing, and further $125 \mathrm{~kg} \mathrm{ha}^{-1}$ of urea- $\mathrm{N}$ fertilization divided into two applications (35 and $50 \mathrm{DAE}$ ).

Plants were submitted to two water treatments: Control (C): normal watering, by sprinkler irrigation system during all cycle, and Stress (S): water suppression for 23 days, starting at 42 days after emergence (DAE), corresponding to blooming. The sprinkler irrigation was maintained with a flow rate of $1.49 \mathrm{~m}^{3} \mathrm{~h}^{-1}$, according assays previously carried out

Table 1. Groups of cotton parents used in the partial diallelic crossing scheme

\begin{tabular}{|c|c|c|c|c|c|}
\hline Parent & Type & Company & Cycle & Fiber color & Main trait \\
\hline \multicolumn{6}{|l|}{ Group I: } \\
\hline FMT 705 & Upland & FMT & Mid-earliness & White & High fiber yield \\
\hline FM 966 & Upland & Bayer & Earliness & White & High fiber yield \\
\hline BRS RUBI & Upland & Embrapa & Mid & Brown & High fiber yield \\
\hline BRS 286 & Upland & Embrapa & Mid-earliness & White & High fiber yield \\
\hline FMT 701 & Upland & FMT & Late & White & High fiber yield \\
\hline CNPA ITA 90 & Upland & Embrapa & Late & White & Water stress tolerant \\
\hline CNPA 5M & Moco & Embrapa & Late & White & Water stress tolerant \\
\hline CNPA 7MH & Hybid & Embrapa & Late & White & Water stress tolerant \\
\hline BRS Seridó & Upland & Embrapa & Mid & White & Water stress tolerant \\
\hline
\end{tabular}


by Bezerra et al. (2010). The plot consisted of two $5 \mathrm{~m}$-rows, spaced in $0.90 \mathrm{~m}$. Plants were spaced in $0.14 \mathrm{~m}$, maintaining a population of 70 plants plot $^{-1}$. A randomized block design was adopted with 20 treatments and 3 repetitions. Plants were maintained free of pests and weeds by using pesticides. At harvest (128 DAE), the following traits were registered: plant height $(\mathrm{PH}, \mathrm{cm})$, cotton seed yield (CSY, $\left.\mathrm{kg} \mathrm{ha}^{-1}\right)$, lint percentage ( $\left.\mathrm{LP}, \%\right)$ and boll weight $(\mathrm{BW}, \mathrm{g})$.

The statistical-genetic analyzes were performed using the GENES program version 6.12014 (Cruz 2016). F and Scott and Knott (1974) tests were adopted to variance analysis (ANOVA) and mean comparisons, respectively. The joint analyses were performed considering genotypes as fixed effect and years and water treatments were random effects (Cruz et al. 2012). A partial diallel analysis model was adopted to genetic analysis, according to Griffing (1956)'s method 4 and adapted by Geraldi and Miranda Filho (1988) in order to estimate the effects of GCA of each parent and the effects of SCA among their combinations.

\section{RESULTS AND DISCUSSION}

Combinations resulting from a partial diallel crosses with upland and Moco cultivars were grown in Barbalha (CE), under irrigation and water suppression (for 23 days) treatments. The physiological symptoms caused by water stress in the plants were observed soon, after the $2^{\text {nd }}$ week of water suppression. In this occasion, plants showed slow growth and reduction in leaf turgidity. At the end of water suppression, irrigation was restored and the symptoms resulting from water stress were disappearing over plant growth.

The results of ANOVA (Table 2 ) showed that significant statistic differences $(p<0.05)$ were verified in Genotype $(G)$, Year $(\mathrm{Y})$ and Water Treatment (WT) to all traits, excepting to boll weight (BW) in year (Y) and water treatment (WT). For these source of variation, the $F$ test uses the interaction $Y \times W T$. As it was very high and significant for this trait, it caused no-significance effect for them ( $Y$ and WT). The same results were seen for $G \times W T$, that uses $G \times Y \times W T$ interaction to test it, indicating different behavior of cultivars submitted to water treatments. On the other hand, the interaction $G \times Y$ did not demonstrate significant effect indicating that the genotypes had similar behaviors in both years (2014 and 2015). The CV values ranged from 2.14 for LP to $10.48 \%$ for CSY, and they are in accordance with the results found by Carvalho et al. (2015), Carvalho et al. (2016) and Zonta et al. (2016) for this crop. The means of traits (Table 3), obtained from different hybrid combinations submitted to two water treatments, demonstrate that the water suppression influenced the growth and production of plants at different levels. For all traits, some hybrid averages showed good potential to develop new genotypes with better performance in water stress condition. The number of groups formed by ScottKnott test ranged from two groups (PH) to seven groups (LP). These results are expected due to the differences among the genetic variability and the influence of the environment in each trait. The reduction in height ranged from 12.88 to $24.71 \%$. This difference promoted a direct impact in yield, with losses ranging from 3.08 to $44.78 \%$. These results explain the effect seen in $\mathrm{G} \times \mathrm{WT}$, in which some combinations were more negatively impacted by water stress, such as FMT $705 \times$ BRS Seridó $(1 \times 9)$ with yield reduced of $44.78 \%$, revealing a highly sensitive genotype. In contrast, BRS 286 x CNPA

Table 2. Synthesis of joint analysis to cotton traits obtained by irrigation and water stress treatments among cotton $\mathrm{F}_{1}$ hybrids

\begin{tabular}{|c|c|c|c|c|c|c|}
\hline \multirow[b]{2}{*}{ SV } & \multirow[b]{2}{*}{ df } & \multicolumn{5}{|c|}{ Means square } \\
\hline & & PH & CSY & LP & BW & B \\
\hline (Block/WT)/Y & 8 & 5.48 & 235850.08 & 1.08 & 0.01 & 2.01 \\
\hline G & 19 & $82.06 * *$ & 7735192.43* & $61.11^{* *}$ & $6.92 * *$ & $4.73 * *$ \\
\hline Y & 1 & $2.84 * *$ & $7364006.66 * *$ & $2.97^{* *}$ & 1.61 & $1.20 * *$ \\
\hline WT & 1 & $26878.06^{* *}$ & $19883526.66 * *$ & $31.56^{* *}$ & 0.24 & $121.00 * *$ \\
\hline$G \times Y$ & 19 & 2.59 & 230650.59 & 0.41 & 0.19 & 0.51 \\
\hline$G \times Y \times W T$ & 19 & 4.12 & 128211.94 & 0.26 & $0.18^{* *}$ & 0.37 \\
\hline Error & 152 & 5.07 & 248601.79 & 0.78 & 0.02 & 0.93 \\
\hline Mean & & 102.62 & 4756.72 & 41.34 & 5.94 & 42.21 \\
\hline CV (\%) & & 2.19 & 10.48 & 2.14 & 2.56 & 2.29 \\
\hline
\end{tabular}

* and **: significant at 5 and $1 \%$ probability, respectively; CV: coefficient of variation; WT: water treatment; Y: year; G: genotype; PH: plant height (cm); CSY: cotton seed yield (kg ha-1); LP: lint percentage (\%); BW: boll weight (g) and B: blooming (DAE). 


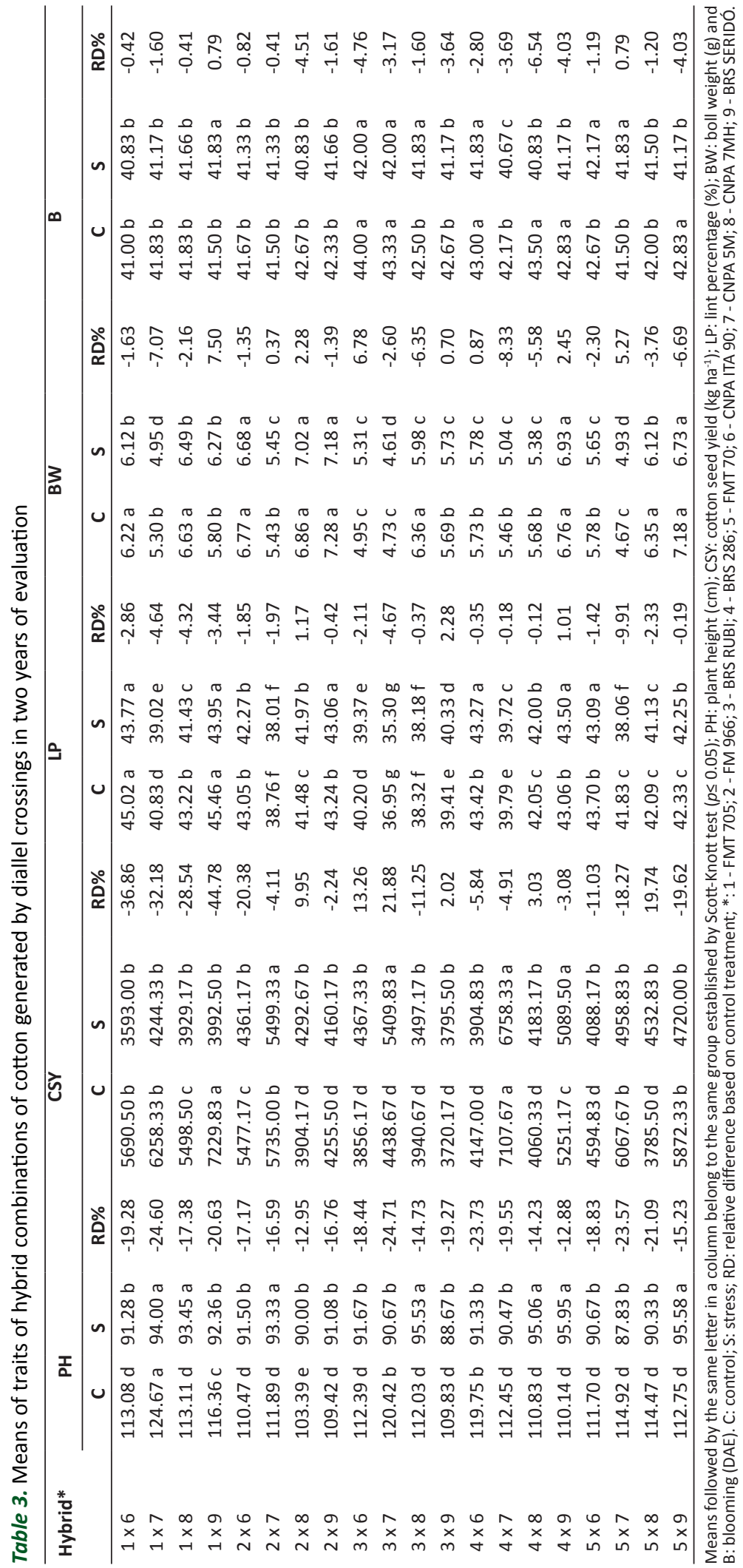

$5 \mathrm{M}(4 \times 7)$ showed an excellent performance, demonstrated by high capacity to produce fibers, even in a situation of water stress, as imposed in this work.

Others five combinations are also productive in water stress conditions, clustered in "a" group, classified by Scott and Knott test: FM $966 \times$ CNPA 5M ( $2 \times 7)$, BRS RUBI x CNPA $5 \mathrm{M}(3 \times 7)$ and BRS $286 \times$ BRS Seridó $(4 \times 9)$, all of them with reduced losses in yield. By the way, BRS RUBI x CNPA 5M $(3 \times 7)$ showed a differential behavior, increasing the yield in $21.88 \%$ in water stress treatment. It means an interesting ability to physiological restoration, which is often associated with tolerance to drought.

Taking in account the others traits, we verified that FM $966 \times$ CNPA $5 M(2 \times 7)$ and BRS $286 \times$ BRS Seridó $(4 \times 9)$ also maintained slight gains for $L P$ and $B W$, in stress treatment. As to blooming, we found that water suppression did not influence hardly in this trait due to it occurred in the period close to flowering (42 DAE). However, we found that the most combinations had a slight earliness to starting the first flower (Table 3). These results agree with Batista et al. (2010) that submitted cotton plants to different methods of irrigation and found that in water stress condition an earlier blooming took place in genotypes. As to Gowda and Hedge (1986), this earliness is often associated to reduction of plant cycle, and it is a desirable feature, especially in environments prone to "indian summer" (veranicos) or water rainfall irregularities. Consequently, the amount of reproductive structures is reduced (Baldo et al. 2009).

The joint diallel analysis of the $F_{1}$ hybrids for cotton traits (Table 4) was performed only under stress treatments in order to select the parents and their hybrid combinations for this condition. A significant effect of GCA was seen in both groups I and II to all traits $(p<0.05)$, excepting to $B$, in GCA-II, indicating additive effects in the control of PH, CSY, LP and BW traits. For SCA, no significant effect was found only to $B W$, indicating non-aditive (dominance or epistasis) to others traits. These results agree with those found by Aguiar et 
al. (2007), Bertini et al. (2005) and Menezes et al. (2013) and mean that, at least, one hybrid combination differs from others, suggesting complementation of favorable alleles between parents, in loci with dominance (Cruz et al. 2012).

These results demonstrate the importance of the GCA and SCA effects in the genetic variance of genotypes, especially GCA in all traits, accounting to whole variance of $24.27 \%$ (PH), $72.13 \%$ (CSY), 93.74\% (LP), 87.64\% (BW) and $64.12 \%$ (B), whose can be exploited in selection procedures of hybrid combinations in order to identify top lines and achieve expressive genetic gains. The effects of interaction G XY, GCA-I XY, GCA-II xY and SCA x Y were all not significant $(p>0.05)$, indicating similar behavior of genotypes during two years in this study. The only exception was found to BW, which revealed significant effect to all interactions, suggesting variations in behavior of parents (GCA-I and II) and hybrids (SCA).

The estimates of GCA ( $\hat{g}$ ) for genotypes of the groups I and II (Table 5 ) detected a significant and distinct contributions from the parents in order to improve the traits of hybrids demonstrating the contribution of diallel crossing to crop improvement, focusing on yield and adaptation to semiarid environment. Highlights were found to BRS 286 (GI) and CNPA 5M (GII) that contributed to increase the yield of hybrids in $515.06 \mathrm{~kg} \mathrm{ha}^{-1}$ and $905.24 \mathrm{~kg} \mathrm{ha}^{-1}$, respectively. BRS 286 (GI) also contributed to increase the height of plants in $1.16 \mathrm{~cm}$. Of course that this trait must be carefully maintained in selection procedures, in order to avoid further problems to mechanical harvesters. According to Chanselme and Ribas (2010), cotton plants should get $90 \mathrm{~cm}$, at most, in the harvest period.

Others cultivars were also more contributive to others traits. FMT 705 (GI), FMT 701 (GI), CNPA ITA 90 (GII) and BRS Seridó (GII) contributed to raising the percentage of lint in 1.92\%, 0.78\%, 1.36\% and 0.98\%, respectively. FMT 705 also contributed to reduce the blooming in 1.09 days. As to BW, both FM 966 and BRS Seridó contributed to increase this trait in about $0.65 \mathrm{~g}$. Based on these results, we conclude that the genetic base of parents used to diallel crossing are important

Table 4. Diallelic analysis of cotton hybrid combinations under water stress condition

\begin{tabular}{|c|c|c|c|c|c|c|}
\hline \multirow[b]{2}{*}{ SV } & \multirow[b]{2}{*}{ df } & \multicolumn{5}{|c|}{ Mean square } \\
\hline & & PH & CSY & LP & BW & B \\
\hline Genotype (G) & 19 & $32.04 * *$ & $3570844.32 * *$ & $30.26^{* *}$ & $3.47^{* *}$ & $4.81^{* *}$ \\
\hline GCA - I & 4 & $19.41 * *$ & $3654532.77^{*}$ & $80.38^{* *}$ & $4.36 * *$ & $12.35^{* *}$ \\
\hline GCA - II & 3 & $23.39 *$ & $11439070.30 * *$ & $72.47 * *$ & $13.48^{* *}$ & 3.05 \\
\hline SCA & 12 & $38.43^{* *}$ & $1575891.34 * *$ & $3.00 * *$ & 0.68 & $2.73^{* *}$ \\
\hline Y & 1 & 0.16 & 449500.20 & 2.18 & $3.38 * *$ & 0.41 \\
\hline$G C A-\| x Y$ & 3 & 1.63 & 33866.95 & 0.25 & $0.35 * *$ & 0.61 \\
\hline SCA $x Y$ & 12 & 0.40 & 104924.92 & 0.44 & $0.47^{* *}$ & 0.61 \\
\hline Error & 76 & 1.56 & 138236.66 & 1.19 & 0.02 & 1.06 \\
\hline Mean & & 92.03 & 4468.89 & 41.71 & 5.91 & 42.92 \\
\hline
\end{tabular}

* and **: significant at 5 and $1 \%$ probability, respectively; Y: year; PH: plant height $(\mathrm{cm})$; CSY: cotton seed yield (kg ha-1); LP: lint percentage (\%); BW: boll weight (g) and B: blooming (DAE).

Table 5. Estimates of GCA ( $\hat{g})$ of cotton parents from groups I and II under water stress condition. Barbalha, CE, 2014-2015

\begin{tabular}{|c|c|c|c|c|c|}
\hline \multirow[b]{2}{*}{ G I } & \multicolumn{5}{|c|}{ Trait } \\
\hline & PH & CSY & LP & BW & B \\
\hline 1. FMT 705 & $0.73^{*}$ & $-529.14^{*}$ & $1.92 *$ & 0.04 & $-1.09 *$ \\
\hline 2. FM 966 & -0.55 & 109.44 & -0.07 & $0.66^{*}$ & $0.74 *$ \\
\hline 3. BRS RUBI & -0.40 & -201.43 & $-2.99 *$ & $-0.51^{*}$ & 0.49 \\
\hline 4. BRS 286 & $1.16^{*}$ & $515.06^{*}$ & 0.36 & $-0.13^{*}$ & -0.25 \\
\hline 5. FMT 701 & $-0.93^{*}$ & 106.06 & $0.78^{*}$ & -0.06 & 0.11 \\
\hline \multicolumn{6}{|l|}{ G II } \\
\hline 6. CNPA ITA 90 & -0.74 & $-405.99 *$ & $1.36^{*}$ & -0.01 & -0.35 \\
\hline 7. CNPA 5M & -0.77 & $905.24^{*}$ & $-2.07^{*}$ & $-0.92^{*}$ & 0.41 \\
\hline 8. CNPA 7MH & 0.83 & $-381.89 *$ & -0.27 & 0.28 & 0.40 \\
\hline 9. BRS SERIDO & 0.69 & -117.35 & $0.98 *$ & $0.64^{*}$ & -0.09 \\
\hline
\end{tabular}

${ }^{*}$ : significant by $t$ test $(p \leq 0.05)$; $\mathrm{PH}$ : plant height $(\mathrm{cm})$; CSY: cotton seed yield (Kg ha $\left.{ }^{-1}\right)$; LP: lint percentage (\%); BW: boll weight (g) and B: blooming (DAE). 
to increase the frequency of favorable alleles, based on the traits studied, allowing to obtain top lines and genetic gain.

The estimates of SCA $\left(\hat{s}_{i j}\right)$ to hybrid combinations (Table 6) presented positive and negative values of $\hat{s}_{i j}$ were obtained in different traits, suggesting deviation of dominance, with alleles that contribute to increase or reduce the expression of traits in loci with dominance. Based on these results, we recommended that the selection procedures of hybrids should be focused in $\mathrm{PH}$ and CSY, since the gains of others traits were zero or negligible, indicating low contribution to plant improvement.

The selection based on height should focus on requirements established to mechanized harvesting. Hybrids that contributed to increase the plant height were: FMT 705 x CNPA 5M, FM 966 × CNPA 5M, BRS RUBI x CNPA 7MH and FMT $701 \times$ x BRS Seridó, demonstrating better adjustment to water stress conditions. On other hand, FM 966 x CNPA $7 \mathrm{MH}$, BRS RUBI x BRS Seridó, BRS 286 x CNPA 5M, FMT $701 \times$ CNPA 5M and FMT $701 \times$ CNPA 7MH can be interesting genotypes selected to reduced height. As to yield, four combinations were highly promising, revealing gains up to 300 $\mathrm{kg} \mathrm{ha}^{-1}$ : BRS 286 x CNPA 5M (869.13 kg ha $\left.{ }^{-1}\right)$, BRS RUBI x CNPA ITA 90 (505.86 kg ha-1), FMT 705 x CNPA 7MH (371.30 kg $\mathrm{ha}^{-1}$ ) and FMT $701 \times$ CNPA 7MH (339.76 kg ha-1). All of them showed high genetic complementation, with potential to generating distinct and top lines.

Cruz et al. (2012) state that in a diallel analysis, the best hybrid combination to be selected must hold a high SCA, with at least one parent with high GCA and associated with high mean. Thus, considering all the features together, we can choose the hybrid BRS $286 \times$ CNPA 5M, BRS RUBI x CNPA 5M, FM 966 × CNPA 5M and BRS $286 \times$ BRS Seridó as the most promising materials for cotton breeding improvement in semi-arid environment. This can lead to build on cotton seed yield and lint percentage gains, reflecting their greater genetic plasticity to tolerate water stress during the reproductive phase, with great opportunities to provide significant genetic gains in the selection process.

The parents used here in diallel crossings are commercial cultivars. They contributed to generate variability and genetic gains to cotton breeding focused on semiarid environment. Also, we found that the additive effects are the most important for yield, lint percentage, blooming and boll weight, while dominance effect are more important to improvement of plant height.

Table 6. Estimates of SCA $\left(\hat{s}_{i j}\right)$ to 20 cotton $\mathrm{F}_{1}$ hybrid combinations grown in stress treatments under water stress condition. Barbalha, 2014-2015

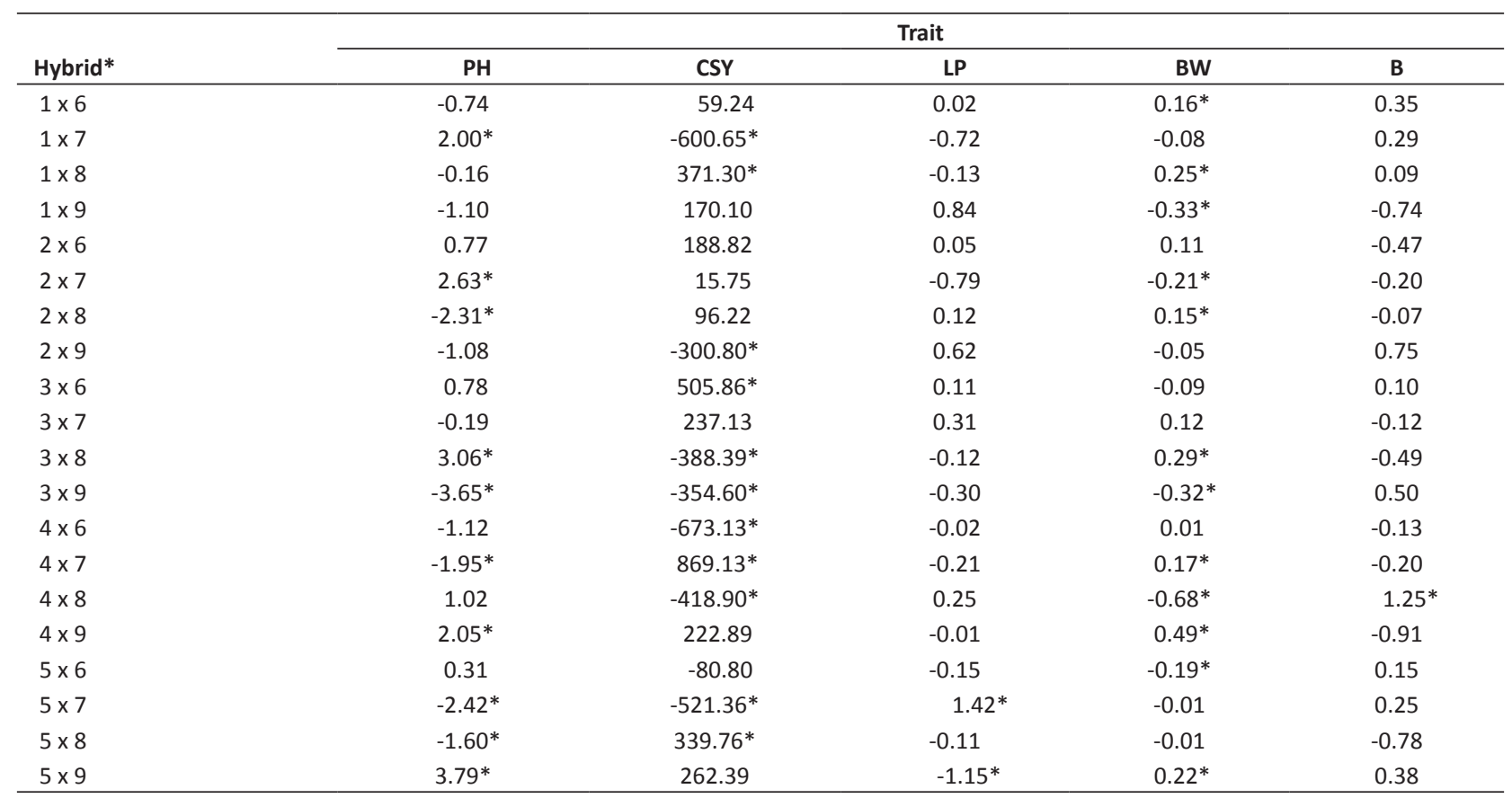

${ }^{*}:$ significant by $t$ test $(p \leq 0.05)$. PH: plant height $(\mathrm{cm})$; CSY: cotton seed yield (Kg ha $\left.{ }^{-1}\right)$; LP: lint percentage (\%); BW: boll weight (g) and B: blooming (DAE); *: 1 - FMT 705 ; 2 - FM 966; 3 - BRS RUBI; 4 - BRS 286; 5 - FMT 70; 6 - CNPA ITA 90; 7 - CNPA 5M; 8 - CNPA 7MH; 9 - BRS SERIDÓ. 
The hybrid combinations: BRS 286 x CNPA 5M, BRS RUBI x CNPA 5M, FM 966 x CNPA 5M and BRS 286 x BRS Seridó were quite promising to advancement of cotton breeding in semiarid environment due to high potential to yield and lint percentage. Those materials showed enough genetic plasticity to adjustment to water stress during the starting of reproductive phase, recovering the productive ability, after drought alleviating. The use of these hybrids in cotton improvement could promote broad opportunities to provide expressive gains in further selection procedures.

\section{REFERENCES}

Abrapa (2016) Associação brasileira dos produtores de algodão. Available at <http://www.abrapa.com.br/estatisticas/paginas/algodao-nobrasil.aspx>. Accessed on June 4, 2016.

Aguiar PA, Penna JCV, Freire EC and Melo LC (2007) Diallel analysis of upland cotton cultivars. Crop Breeding and Applied Biotechonology 7: $353-359$.

Baldo R, Scalon SPQ, Rosa YBCJ, Mussury RM, Betoni R and Barreto WS (2009) Comportamento do algodoeiro cultivar Delta Opal sob estresse hídrico com e sem aplicação de bioestimulante. Ciência e Agrotecnologia 33: 1804-1812.

Batista CH, Aquino LA, Silva TR and Silva HRF (2010) Crescimento e produtividade da cultura do algodão em resposta a aplicação de fósforo e métodos de irrigação. Revista Brasileira de Agricultura Irrigada 4: 197-206.

Bertini CHCM, Schuster I, Sediyama T, Barros EG and Moreira MA (2005) Analysis of cotton genetic diversity by microsatellites and pedigree. Crop Breeding and Applied Biotechnology 5: 369-378.

Bezerra JRC, Azevedo PV, Silva BB and Dias JM (2010) Evapotranspiração e coeficiente de cultivo do algodoeiro BRS-200 Marron, irrigado. Revista Brasileira de Engenharia Agrícola e Ambiental 14: 625-632.

Carvalho LP, Farias FJP, Lima MMA and Rodrigues JIS (2016) Inheritance of diferente fiber colors in cotton (Gossypium barbadense L.). Crop Breeding and Applied Biotechnology 14: 256-260.

Carvalho LP, Salgado CC, Farias FJF and Carneiro VQ (2015) Estabilidade e adaptabilidade de genótipos de algodão de fibra colorida quanto aos caracteres de fibra. Ciência Rural 45: 598-605.

Chanselme JL and Ribas PV (2010) Beneficiamento do algodão adensado e qualidade de fibra. In Belot JL and Vilela PMCA (eds) O sistema de cultivo do algodoeiro adensado em Mato Grosso. IMA-MT, Cuiabá, p. 311-327.

Cia E, Fuzatto MG, Almeida WP, Kondo JI, Ito MF and Dias FLF (2014) Reaction of cotton genotypes to Alternaria leaf spot. Summa Phytopathologica 40: 81-83.

Conab - Companhia Nacional de Abastecimento (2016) Available at http://www.conab.gov.br>. Acessed on June 4, 2016.

Coutinho CR, Andrade JAS and Pegoraro RF (2015) Produtividade e qualidade de fibra de cultivares de algodoeiro (Gossypium hirsutum L.) na região do semiárido mineiro. Essentia 16: 62-82.
Cruz CD (2016) Genes software - estendido e integrado com o R, Matlab e Selegen. Acta Scientiarum. Agronomy 38: 547-552.

Cruz CD, Regazzi A and Carneiro PCS (2012) Análise dialélica. In Cruz CD (ed) Modelos biométricos aplicados ao melhoramento genético. Editora UFV, Viçosa, p. 236-367.

Embrapa - Empresa Brasileira de Pesquisa Agropecuária (1999) Sistema brasileiro de classificação de solos. Embrapa Solos, Rio de Janeiro, 412p.

FAO - Organização das Nações Unidas para Alimentação e Agricultura (2015) OCDE-FAO Perspectivas Agrícolas 2015-2024. Available at <https:// http://www.fao.org/publications/card/ en/c/2153c9156478-4c40-92ee-ff0f583bb264>. Accessed on June 4, 2016.

Freire EC, Medeiros JC, Silva CAD, Azevedo DMP, Andrade FP and Vieira DJ (1999) Cultura dos algodoeiros mocó precoce e Algodão 7MH. Embrapa, local?, 65p. (Circular técnica, 28).

Geraldi IO and Miranda Filho JB (1988) Adapted models for the analysis of combining ability of varieties in partial diallel crosses. Brazilian Journal of Genetics 11: 419-430.

Gowda A and Hegde BR (1986) Moisture stress and hormonal influence on the flowering behavior and yield of groundnut. Plant Physiology 66: 835-837.

Griffing B (1956) Concept of general and specific ability in relation to diallel crossing systems. Australian Journal of Biological Sciences 9: 462-469.

Khan N and Hassan G (2011) Genetic effects on morphology and yield of cotton (Gossypium hirsutum L.). Spanish Journal of Agricultural Research 9: 460-472.

Menezes IPP, Hoffmann LV and Barroso AV (2015) Genetic characterization of cotton landraces found in the Paraiba and Rio Grande do Norte states. Crop Breeding and Applied Biotechnology 15: 26-32.

Raza MM, Munawar M, Hammad G, Aslam R, Habib S and Latif A (2013) Genetic analysis of some metric plant traits in upland cotton (Gossypium hirsutum L.) through hybridization. Universal Journal of Plant Science 1: 1-7.

Scott AJ and Knott M (1974) A cluster analysis method for grouping means in the analysis of variance. Biometrics 30: 507-512.

Vidal Neto FC and Freire EC (2013) Melhoramento genético do algodoeiro. In Vidal Neto FC and Cavalcanti JJV (eds) Melhoramento genético de plantas no Nordeste. Embrapa, Brasília, p. 49-83.

Zonta JH, Brandão ZN, Sofiatti V, Bezerra JR and Medeiros JC (2016) Irrigation and nitrogen effects on seed cotton yield, water productivity and yield response factor in semi-arid environment. Australian Journal of Crop Science 10: 118-126.

(cc) EY This is an Open Access article distributed under the terms of the Creative Commons Attribution License, which permits unrestricted use, distribution, and reproduction in any medium, provided the original work is properly cited. 